Original Research Paper

\title{
Evaluation of Nutritional Quality of Some Wild Edible Plants in Central Cross River, Nigeria
}

\author{
${ }^{1}$ Obi-Abang Magdalene, ${ }^{2}$ Margaret Akpana Agiang, ${ }^{3}$ Victor Eshu Okpashi and ${ }^{2}$ Godwin Eneji Egbung \\ ${ }^{I}$ Department of Chemical Science, Cross River University of Technology, Calabar, Nigeria \\ ${ }^{2}$ Department of Medical Biochemistry, University of Calabar, Nigeria \\ ${ }^{3}$ Department of Biochemistry, University of Nigeria, Nsukka, Nigeria
}

Article history

Received: 11-02-2018

Revised: 25-04-2018

Accepted: 09-05-2018

\section{Corresponding Author:}

Victor Eshu Okpashi

Department of Biochemistry,

University of Nigeria, Nsukka,

Nigeria

Email: vic2reshu@gmail.com

\begin{abstract}
According to the Nigerian National Population Commission 2006, the population of the nation was conservatively estimated to be over one hundred and seventy million. The challenge of nutritional quality to feed an increasing national population places a higher demand on poorly grown conventional plants. Thus the need to incorporate wild edible plants to bridge the extended gap between the conventional vegetable and the wild indigenous edible plants informs this research. The daily intake of vitamins and minerals are obtained from vegetables. Wild edible plants serve as food and medicine. In this study, the delicacies were prepared from two novel wild edible vegetables - Ceiba Pentandra (CPD) and Ficus glumosa (FGD). They were evaluated for nutritional quality. Their minerals and vitamins content were determined using standard methods. These delicacies were fortified with a diet of experimental rats. Twenty four (24) albino rats weighing $43.99-81.49 \mathrm{~g}$ were randomly arranged into six groups $(\mathrm{n}=6)$ of six rats per group. Two groups were fed with the formulated experimental diets, while the other two were fed with protein-free (casein) and basal diets. Vitamins $\mathrm{C}$ and $\mathrm{E}$, carbohydrate and protein were significant in CPD delicacy at $(28.47 \pm 3.17 \%)$. The mineral composition showed low $\mathrm{Na}^{+}$level, while $\mathrm{Ca}^{2+}$ concentration was also low in CPD and FGD. Phosphorus and $\mathrm{Mg}^{+2}$ were high in FGD. The FGD-fed rats had a low biological value (\%) $(1.38 \pm 0.01 \%)$ compared to CPD $(2.29 \pm 0.01)$ and reference (casein) group $(3.02 \pm 0.01)$. The reference group consumed the highest amount of food $97.06 \pm 14.70 \mathrm{~g}$, followed by the basal group $(88.98 \pm 10.61$, with CPD having (76.46 \pm 18.78$)$ and FGD $(48.27 \pm 18.27)$, respectively. There were no differences in the body weight, protein efficiency ratio, net protein utilization, net protein retention, true digestibility, fecal and carcass protein levels in all the test groups. Findings indicate that nutrients from these wild vegetable delicacies may have good quality and could meet the nutritional needs of the consumer if utilize as per the standard.
\end{abstract}

Keywords: Delicacies, Wild Vegetable, Nutrition, Ceiba pentandra and Ficus glumosa

\section{Introduction}

Historically, before the advent of animals and plants domestication, all humans lived as nomadic owing to their absolute reliance on animals and plants for food (Kwazo et al., 2015). As people gained knowledge about plants' growth, the practice of domesticating plants commenced (Barker, 2006). Subsequently, humans transited from hunting and gathering to agricultural practices. Agrarian revolution (sometimes called
Neolithic revolution) was reported to have started in Southeast Asia about 10,000 years ago and spread to other parts of the world (Pollard et al., 2015). The migration of people during the pre-agricultural era exposed people to many different wild edible plants (Shermer, 2002). This accounted for their high resistance to diseases/infections and low mortality rate. In contrast, as agriculture begins to gain momentum; farming activities resulted in the selective breeding of edible plants which narrow the nutritional diversity (Barker, 2006). 
However, effective way of tackling nutritional insufficiency especially in developing countries could be the promotion of increased consumption of nutritious wild indigenous edible plants (Álvaro and Burlingame, 2006). A larger number of these nutritious plants still exist in the wild and are distributed in vast ecological zones (Freedman, 2015).

Ceiba pentandra plant is also known as "kapok tree", "Fromager" (in French), "Otorokpa" (in Yala, Cross River State). It is a massive tree which grows to about $200 \mathrm{~m}$ height (Hellmuth, 2011). The seeds are edible, while its young leaves are used to prepare soup in some localities (Friday et al., 2011). Ceiba pentandra plant can elicit hepatoprotective responses against paracetamol-induced hepatotoxicity in rats. It also possesses angiogenesis, antihelminthic activities and diverse pharmacological spectrum (Elumalai et al., 2012). Ficus glumosa is called the mountain fig or African rock fig; its local names in Nigeria are "Kudung" (in Obudu dialect) and "Baure" (Hausa). F. glumosa is a tree of small to medium size which grows to $5.0-10 \mathrm{~m}$ tall and $50 \mathrm{~cm}$ in diameter (Ntchapda et al., 2015). When ripe, its red-coloured edible fruits are succulent, sweet and flavorsome. The young leaves are consumed as vegetables in local delicacies (Ntchapda et al., 2015). These plants are capable of improving human nutrition and offsetting the insecurity associated with food quality by serving as a buffer especially during the time of food shortages (Diehl et al., 2004). In order to enhance the diets of vulnerable populations, it is necessary to factor the qualitative aspect of the nutritional value of such diets (Heywood, 2011). Considering the rapid decline in knowledge about the diversity of wild plants, their choices as foods are difficult to establish due to toxicity and intoxication Weidmann and Craik (2016). In the local communities, consumers are poorly informed on the nutritional benefits of some delicacies with respect to the basic nutrients and anti-nutrients or general food quality. Incidences of delicacies shortages usually arise when the anticipated harvest of cultivated plants has not been achieved and/or when there is depletion of stored dietary resources. The seasonal scarcity of important edible plants also limits the availability of popular foodstuffs (Bhattarai et al., 2009). Aggravating these unfortunate scenarios is the challenge of feeding an increasing world population which places a higher demand on the already poorly grown conventional plants. Therefore, the need to incorporate wilder edible plants to bridge the wide-spread gap between the conventional vegetable and the wild indigenous edible plants informs this research.

\section{Materials and Methods}

\section{Collection and Identification of Vegetables}

The vegetables were randomly collected from Cross River State, Nigeria as follows: Ceiba pentandra
"Otorokpa" - Okpoma, Yala and Ficus glumosa "Kudung" by the Abochiche, Bekwarra people. They were verified and authenticated by Dr. S. Udo Department of Biological Science, Cross River University of Technology, Calabar. Besides the vegetables, all the food ingredients used for the preparation of the delicacies were purchased from Watt market Calabar, Cross River State, Nigeria.

\section{Methods of Preparing Delicacies}

The selected fresh vegetables were thoroughly cleaned under running tap water and used to prepare the delicacies based on the traditional recipes of the study area: Ficus Glumosa Delicacy (FGD) and Ceiba pentandra delicacy (CPD) delicacies were blended into pastes using an electric hand blender after which they were dried in a hotair circulating oven at $70^{\circ} \mathrm{C}$ for $24 \mathrm{hr}$. They were then removed, ground into powder using a pistle/mortar, poured into airtight containers and properly stored in a refrigerator $\left(3-5^{\circ} \mathrm{C}\right)$ for analyses.

\section{Chemical Analysis}

The following methods were adopted for analysis of properties. Determination of fiber, Ash content estimation, Vitamin analyses, mineral elements and total carbohydrates (AOAC, 1995) method.

Determination of energy values, antinutritional elements Onyeike et al. (2000). Determination of oxalic acid (Munro and Bassir (1969), Phytate (Onwuka, 2005). Analysis of hydrogen cyanide was done according to the method prescribed by Agbaire (2011).

\section{Statistical Analysis}

The data obtained were analyzed using SPSS statistical package (version 20.0) and results expressed as the mean \pm standard deviation. Between the means, significant differences were established by one way ANOVA at $P<0.05$ followed by least square difference (LSD) post-hoc test.

\section{Results}

Table 1 represents the different components of the test samples, beginning with the basal diet, reference diet, CPD delicacy and FGD delicacy. There composition comprised of cornstarch, casein, test material, sucrose, glucose, soy oil, cellulose, vitamin and mineral. There are summed to 1200 and bear different amounts, respectively. The cornstarch was purchased from marina market in Calabar municipality, while the components of mineral and vitamin mix were gotten from a scientific shop in Calabar. 


\section{Vitamin Content}

The different Vitamins - A, C and E content $(\mu \mathrm{g} / 100$ g) showed observable variation among the delicacies. The Ceiba pentandra (CPD) had the highest amount of vitamin A, while the Ficus glumosa (FGD) had the highest Vitamin A and lowest vitamin E content. Comparatively, each delicacy varies considerably from one other in vitamin E content (Table 2).

\section{Mineral Content}

The essential mineral content $(\mathrm{mg} / 100 \mathrm{~g})$ of the delicacies - magnesium $\left(\mathrm{Mg}^{2+}\right)$, sodium $\left(\mathrm{Na}^{+}\right)$, calcium $\left(\mathrm{Ca}^{2+}\right)$ and Phosphorus (P) is shown in Table 3. There was observable difference in $\mathrm{Mg}^{2+}$ concentration of delicacies - Ficus glumosa (FGD) and Ceiba Pentandra (CPD). The test samples showed low $\mathrm{Na}^{+}$content except for Phosphorus, $\mathrm{Ca}^{2+}$ and $\mathrm{Mg}^{2+}$, respectively.

\section{Biological Evaluation (Food Intake)}

The rats fed with reference (casein) diet consumed the highest amount of food ( $\mathrm{g}$ ) followed by group fed with basal (protein-free) diet, although the difference was statistically non-significant. Data in Table 4 shows that the groups fed with FGD and CPD recorded the lowest food intake during the experimental period compared to the basal and reference group.

\section{Body Weight Changes}

Body weight changes (g) of rats measured during 10 days of the study are presented in Table 5. It was observed that there were no significant differences among the treated groups at $P<0.05$

Results showed non-significant differences among the treated groups at $P<0.05$ as regards their Protein Efficiency Ratio (PER). Among the treated groups, there were no observable significant differences $(P<0.05)$ in Net Protein Utilization (NPU). No significant differences were detected in the Net Protein Ratio (NPR) among the treated groups $(P<0.05)$. The True Digestibility (TD) of the experimental animals showed no observable significant differences among the groups at $P<0.05$. The Biological Values (BV) of all the sample groups were significantly different from each other with the reference diet and Ficus Glumosa Delicacy (FGD) administered groups having the highest and lowest biological values, respectively see Table 6 .

Test groups with no superscripts are significantly different at $\mathrm{P}<0.05 . \mathrm{n}=6$. For Protein Efficiency Ratio (PER), Net Protein Utilization (NPU), Net Protein Retention (NPR), True Digestibility (TD) and Biological Values (BV) of rats fed with Ceiba Pentandra Delicacy (CPD), Ficus Glumosa Delicacy (FGD), basal diet and Reference diet. Test groups with identical superscripts are not significantly different at $\mathrm{P}<0.05$.

Table 7 showed that the fecal protein (FePr) content (\%) among the groups, they were not significantly different from one another $(P<0.05)$. The carcass protein content $(\%)$ of the delicacies showed observable significant differences between groups at $p<0.05$. The overall trend was in the decreasing order of Ceiba Pentandra Delicacy (CPD), basal diet, Reference diet and Ficus Glumosa Delicacy (FGD) groups.

Table 1: Composition of the Experimental Diets

\begin{tabular}{|c|c|c|c|c|}
\hline Components & Basal diet & Reference diet & Test delicacy 1 (CPD) & Test delicacy 2 (FGD) \\
\hline Cornstarch & 840 & 720 & 418 & 3 \\
\hline Casein & - & 120 & - & - \\
\hline Test material & - & - & 422 & 1,162 \\
\hline Sucrose & 120 & 120 & 120 & 3 \\
\hline Glucose & 60 & 60 & 60 & 3 \\
\hline Soy oil & 60 & 60 & 60 & 3 \\
\hline Cellulose & 60 & 60 & 60 & 5 \\
\hline Vitamin mix & 12 & 12 & 12 & 6 \\
\hline Mineral mix & 48 & 48 & 48 & 15 \\
\hline Total & 1200 & 1200 & 1200 & 1200 \\
\hline
\end{tabular}

Test delicacy 1: Ceiba Pentandra Delicacy (CPD)

Test delicacy 2: Ficus Glumosa Delicacy (FGD)

Basal diet: Protein-free diet

Reference diet: Casein-based diet.

Table 2: Vitamins Concentration in Delicacies

\begin{tabular}{llll}
\hline Delicacies & Vitamin A $(\mu \mathrm{g} / 100 \mathrm{~g})$ & Vitamin C $(\mathrm{mg} / 100 \mathrm{~g})$ & Vitamin E $(\mu \mathrm{g} / 100 \mathrm{~g})$ \\
\hline CPD & $106.83 \pm 0.06$ & $64.07 \pm 2.98$ & $6.30 \pm 0.26$ \\
FGD & $95.83 \pm 0.35$ & $56.90 \pm 1.40$ & $5.77 \pm 0.31$ \\
\hline Test groups with no identical superscripts are significantly different at $p<0.05 . \mathrm{n}=3$, for Vitamin A $(\mu \mathrm{g} / 100 \mathrm{~g})$, vitamin C $(\mathrm{mg} / 100$
\end{tabular}
$g)$ and vitamin $E(\mu \mathrm{g} / 100 \mathrm{~g})$ of Ceiba pentandra (CPD) and Ficus glumosa (FGD) delicacies. 
Table 3: Mineral composition of delicacies

\begin{tabular}{lllll}
\hline Delicacies & Calcium $(\mathrm{mg} / 100 \mathrm{~g})$ & Magnesium $(\mathrm{mg} / 100 \mathrm{~g})$ & Phosphorus $(\mathrm{mg} / 100 \mathrm{~g})$ & Sodium $(\mathrm{mg} / 100 \mathrm{~g})$ \\
\hline CPD & $61.90 \pm 0.66^{\mathrm{b}}$ & $68.43 \pm 1.91^{\mathrm{b}}$ & $29.90 \pm 0.70^{\mathrm{a}}$ & $9.80 \pm 0.20^{\mathrm{a}, \mathrm{b}}$ \\
FGD & $59.53 \pm 0.85^{\mathrm{b}}$ & $73.30 \pm 1.71^{\mathrm{a}}$ & $33.53 \pm 0.67$ & $9.70 \pm 0.56^{\mathrm{a}, \mathrm{b}}$ \\
\hline
\end{tabular}

Test groups with identical superscripts are not significantly different at $p<0.05$ while test groups with non-identical superscripts are significantly different at $p<0.05 . n=3$, for contents of selected minerals (mg/100g) of Ceiba pentandra (CPD) and Ficus glumosa (FGD) delicacies.

Table 4: Food Intake by dietary groups

\begin{tabular}{ll}
\hline Dietary groups & Amount of Food intake (g) \\
\hline CPD & $76.46 \pm 18.78^{\mathrm{b}}$ \\
FGD & $48.27 \pm 18.27^{\mathrm{a}}$ \\
Basal & $88.98 \pm 10.61^{\mathrm{b}, \mathrm{c}}$ \\
Reference diet & $97.06 \pm 14.70^{\mathrm{c}}$ \\
\hline
\end{tabular}

Test groups with identical superscripts are not significantly different at $p<0.05$, while test groups with non-identical superscripts are significantly different at $P<0.05 . n=6$. For the food intakes ( $g$ ) of rats fed with Ceiba pentandra delicacy (CPD), Ficus glumosa delicacy (FGD), and basal diet and Reference diet.

Table 5: Body weight changes of rats fed reference, basal and experimental diets

\begin{tabular}{llll}
\hline Dietary groups & Initial weight & Final weight & Body weight changes \\
\hline CPD & $65.72 \pm 2.62$ & $71.12 \pm 8.91$ & $5.40 \pm 4.07^{\mathrm{a}}$ \\
FGD & $66.62 \pm 0.47$ & $72.69 \pm 7.75$ & $6.07 \pm 4.85^{\mathrm{a}}$ \\
Basal & $72.33 \pm 1.87$ & $75.17 \pm 3.14$ & $2.84 \pm 1.65^{\mathrm{a}}$ \\
Reference diet & $78.74 \pm 2.16$ & $84.18 \pm 4.84$ & $5.44 \pm 3.05^{\mathrm{a}}$ \\
\hline
\end{tabular}

Test groups with identical superscripts are not significantly different at $p<0.05 . n=6$. The initial weight, final weight, and the change in body weight (g) of the rats fed with Ceiba pentandra delicacy (CPD), Ficus glumosa delicacy (FGD) and basal diet and Reference diet.

Table 6: Biological evaluation of rats fed reference, basal and experimental diets

\begin{tabular}{llllll}
\hline Dietary groups & PER & NPU & NPR & TD & BV \\
\hline CPD & $0.54 \pm 0.41^{\mathrm{a}}$ & $0.03 \pm 0.01^{\mathrm{a}}$ & $0.27 \pm 0.13^{\mathrm{a}}$ & $1.13 \pm 1.06^{\mathrm{a}}$ & $2.29 \pm 0.01$ \\
FGD & $0.61 \pm 0.49^{\mathrm{a}}$ & $0.04 \pm 0.02^{\mathrm{a}}$ & $0.51 \pm 0.39^{\mathrm{a}}$ & $2.77 \pm 2.06^{\mathrm{a}}$ & $1.38 \pm 0.01$ \\
Basal & $0.29 \pm 0.16^{\mathrm{a}}$ & - & - & - & - \\
Reference diet & $0.54 \pm 0.30^{\mathrm{a}}$ & $0.01 \pm 0.00^{\mathrm{a}}$ & $0.36 \pm 0.20^{\mathrm{a}}$ & $0.46 \pm 0.32^{\mathrm{a}}$ & $3.03 \pm 0.01$ \\
\hline
\end{tabular}

Test groups with no superscripts are significantly different at $p<0.05 . n=6$. For Protein efficiency ratio (PER), net protein
utilization (NPU), net protein retention (NPR), true digestibility (TD) and biological values (BV) of rats fed with Ceiba pentandra delicacy (CPD), Ficus glumosa delicacy (FGD), basal diet and Reference diet. Test groups with identical superscripts are not significantly different at $P<0.05$.

Table 7: Faecal and carcass protein of experimental rats

\begin{tabular}{lll}
\hline Dietary groups & Fecal protein (\%) & Carcass protein (\%) \\
\hline CPD & $16.47 \pm 3.06^{\mathrm{a}}$ & $48.11 \pm 3.20^{\mathrm{a}}$ \\
FGD & $16.57 \pm 3.29^{\mathrm{a}}$ & $30.99 \pm 3.39^{\mathrm{c}}$ \\
Basal & $12.89 \pm 0.37^{\mathrm{a}}$ & $37.40 \pm 8.25^{\mathrm{b}}$ \\
Reference diet & $14.43 \pm 1.25^{\mathrm{a}}$ & $35.60 \pm 2.99^{\mathrm{b}, \mathrm{c}}$ \\
\hline
\end{tabular}

Test groups with identical superscripts are not significantly different at $P<0.05$ whereas test groups with non-identical superscripts are significantly different at $P<0.05 . n=6$. Fecal and carcass protein (\%) of rats fed with (CPD), Ficus glumosa delicacy (FGD), basal diet and reference diet.

\section{Discussion}

The major aim of conducting an investigation on wild edible food plants is for the purpose of documentation of available indigenous plants for consumption and awareness. Comparative analysis on wild edible plants (WEPs) in different societies and ethnic settings among countries may include the recognition of most widely consumed species for nutritional quality assessment
(De Caluwé et al., 2010). Abiotic components (rainfall, soil and temperature) and agronomic practices are factors responsible for the differences in plants' nutrients concentration (Imran et al., 2007). The composition of different dietary regiment comprised of cornstarch, casein, test material, sucrose, glucose, soy oil, cellulose, vitamin and mineral. There are summed to 1200 and bear different amounts, respectively. For instance, among the delicacies - Ceiba Pentandra (CPD) and Ficus Glumosa 
(FGD) for their composition of the experimental diets had, the composition of cornstarch in basal diet was 840, reference diet 728, CPD 418, while FGD had the lowest 3 see Table 1. Also other components level differs with experimental diets. According to Khan et al. (2016), food from plant sources is regarded as a good source of vitamins and minerals. The cardinal functions of vitamins are for enhancement of growth and development (Mutiara et al., 2013). They are the main sources of nitrogenous compounds (Adamczyk et al., 2010). The vitamins and elemental analyses of Ceiba Pentandra (CPD) and Ficus Glumosa (FGD) delicacies showed the observable variation among the delicacies for Vitamins - A, C and E concentration $(\mu \mathrm{g} / 100 \mathrm{~g})$ in Table 2 and the essential mineral content $(\mathrm{mg} / 100 \mathrm{~g})$ of the delicacies - magnesium $\left(\mathrm{Mg}^{2+}\right)$, sodium $\left(\mathrm{Na}^{+}\right)$, calcium $\left(\mathrm{Ca}^{2+}\right)$ and phosphorus $(\mathrm{P})$ is shown in Table 3 . There was an observable difference in $\mathrm{Mg}^{2+}$ concentration of delicacies - Ficus Glumosa (FGD) and Ceiba Pentandra (CPD). The test samples showed low $\mathrm{Na}^{+}$content except for Phosphorus, $\mathrm{Ca}^{2+}$ and $\mathrm{Mg}^{2+}$, respectively. The Ceiba Pentandra (CPD) had the highest amount of vitamin A, while the Ficus glumosa (FGD) had the highest Vitamin $\mathrm{A}$ and lowest vitamin E content. Comparatively, each delicacy varies considerably from one other in vitamin $\mathrm{E}$ content see (Table 2). This was consistent with Udo et al. (2013), who reported the high levels of vitamins in Ficus glumosa vegetable relative to Ceiba pentandra vegetable. This output was replicated in the energy difference between FGD and CPD. These plants could play a major part as a source of energy and micronutrients (De Caluwé et al., 2010; Ermias et al., 2011). Recently, preliminary researches on the dietary analysis of some WEPs provide promising knowledge on the advocacy and orientation about the need for consuming WEP.

The biological evaluation on the intake of food by rats indicated that rats fed with reference (casein) diet consumed the highest amount of food (g) next by the group fed with basal (protein-free) diet, though the difference was statistically non-significant or different, data in Table 4 shows that the groups fed with FGD and CPD recorded the lowest food intake $\left(48.27 \pm 18.27^{\mathrm{a}} \mathrm{g}\right.$ and $\left.76.46 \pm 18.78^{\mathrm{b}} \mathrm{g}\right)$ during the experimental period relative to the basal and reference group $\left(88.98 \pm 10.61^{\mathrm{b}, \mathrm{c}}\right.$ $\mathrm{g}$ and $97.06 \pm 14.70^{\mathrm{c}} \mathrm{g}$ ), respectively. It is correct to say that during cooking/heating, some mineral elements leached into the medium, this agreed with (Nelson and Cox, 2012; Bernhardt and Schlich, 2006) assertion that during cooking, minerals are not destroyed by heat but leached into the fluid medium. The optimal functioning of the body requires vitamins and mineral elements in many biochemical processes e.g. blood clotting, enzymatic activation, neuromuscular activities, formation/development of bone and teeth (Hussain and Khan, 2010; Khan et al., 2016). In the intracellular domain, the most abundant divalent cation is magnesium (Siddique and Prakash, 2014). It helps in the maintenance of cardiovascular tone and cofactor in reactions catalyzed by enzymes (Vaskonen, 2003). Sodium and phosphorus contribute significantly to many physiological processes such as transport of biomolecules, energy generation and homeostasis (Esmaeili et al., 2014). Besides other important components of the delicacies, vitamins showed considerable concentration. Vitamins are necessary antioxidants that aid the scavenging of noxious free radicals in the body (Janu et al., 2014).

Comparatively, research conducted by (Adotey et al., 2009; Singhal et al., 2016), both found variations in concentrations of essential elements for different vegetables, for instance, Adotey et al. (2009) observed calcium in tomato to vary from 0.002 to $0.24 \mathrm{~g} / \mathrm{kg}$ with a mean of $0.17 \mathrm{~g} / \mathrm{kg}$. The calcium in garden egg ranged from 0.01 to $0.16 \mathrm{~g} / \mathrm{kg}$ with a mean of $0.10 \mathrm{~g} / \mathrm{kg}$. The content of calcium in onion was $0.60 \mathrm{~g} / \mathrm{kg}$ and ranges from 0.44 to $0.88 \mathrm{~g} / \mathrm{kg}$. Singhal et al. (2016) observed the concentration of sodium to range from $33 \mathrm{mg} / \mathrm{kg}$ to $390 \mathrm{mg} / \mathrm{kg}$, while Calcium varies from $140 \mathrm{mg} / \mathrm{kg}$ to 780 $\mathrm{mg} / \mathrm{kg}$. Concentration of $\mathrm{Fe}$ was $2.5 \pm 0.2 \mathrm{mg} / \mathrm{kg}$ to $6.75 \pm 0.42 \mathrm{mg} / \mathrm{kg}$ in different vegetables. Essential element concentration was found to be least in Potato while it was highest in Cabbage. This variability in the content of the element is due to the nature of the plant, site of plantation and translocation capacity of the plant to accumulate and partition the metals. However average daily levels of sodium intake for adult range from 2 to 5 $\mathrm{g}$ (WHO, 1979, cited in Singhal et al. (2016)

The changes in body weight $(\mathrm{g})$ of rats measured during 10 days of the study are presented in Table 5. It was observed that there were no significant differences among the treated groups at $P<0.05$. But the changes in the body weights of rats fed reference, basal and experimental diets showed that Protein Efficiency Ratio (PER), Net Protein Utilization (NPU), Net Protein Retention (NPR) and True Digestibility (TD) of the experimental animals had no significant differences among the groups see Table 6. Proteins influence body weight, but a decrease in protein quality may lead to lower body weights and vice versa (Sandi et al., 2016). Apparently, variations in growths among the groups were not different as suggested by the observed non-significant differences in the rats' body weight, true digestibility, protein efficiency ratio; net protein utilization, net protein retention, fecal and carcass levels of proteins see Table 7 . However, the relatively increased food intake and high quality of the reference diet may have accounted for the corresponding high biological value shown by the respective tested groups compared to the non-test groups. Therefore, considering these results, one can deduce that consumption of this wild Ceiba pentandra and Ficus glumosa delicacies will be beneficial to human health due to their nutritional value, irrespective of whether there are wild or cultivated. 


\section{Conclusion}

This study provided basic information on the nutritional profile and benefits of Ceiba pentandra and Ficus glumosa delicacies which are not readily available in our localities and cities. These novel wild edible vegetables can contribute to food quality and provide essential nutrient required by the body. These wild edible plants can play a beneficial role in scrimmaging food insecurity challenges in Nigeria and Africa.

\section{Acknowledgement}

We are thankful to the supervisor for taking her time, editing the manuscript and superving the investigation.

\section{Author's Contributions}

Obi-Abang Magdalene: Did both the laboratory and field work.

Margaret Akpana Agiang: Designed the work and supervised.

Victor Eshu Okpashi: Wrote the manuscript and laboratory work.

Godwin Eneji Egbung: Supply the relevant literature.

\section{Ethics}

Authors hereby declare no competing interest regarding the publication of this article.

\section{References}

AOAC, 1995. Association of Official Analytical Chemist: Official Methods of Analysis, 16th Edn., Washington, U.S.A.

Adamczyk, B., A. Smolander, V. Kitunen and M. Godlewski, 2010. Proteins as nitrogen source for plants. A short story about exudation of proteases by plant roots. Plants Signaling Behaviour, 5: 817-819. DOI: $10.4161 / \mathrm{psb}$.5.7.11699

Adotey, D.K., Y. Serfor-Armah, J.R. Fianko and P.O. Yeboah, 2009. Essential elements content in core vegetables grown and consumed in Ghana by instrumental neutron activation analysis. African J. Food Sci., 3: 243-249.

Agbaire, P., 2011. Nutritional and anti-nutritional levels of some local vegetables (Vernomia anydalira, Manihot esculenta, Teiferia, occidentalis, Talinum triangulare, Amaranthus spinosus) from Delta State, Nigeria. J. Applied Sci. Environ. Manage., 15: 625-628.

Barker, G., 2006. The Agricultural Revolution in Prehistory: Why Did Foragers Become Farmers. 1st Ed, Oxford University Press, Oxford, ISBN-10: 0191557668, pp: 616.
Bernhardt, S. and E. Schlich, 2006. Impact of different cooking methods on food quality: Retention of lipophilic vitamins in fresh and frozen vegetables. J. Food Eng., 77: 327-333.

DOI: 10.1016/j.jfoodeng.2005.06.040

Bhattarai, S., R.P. Chaudhary and R.S.L. Taylor, 2009. Wild edible plants used by the people of Manang district, Central Nepal. Ecology Food Nutrition, 48: 1-20. DOI: 10.1080/03670240802034996

Álvaro, T. and B. Burlingame, 2006. Biodiversity and nutrition: A common path toward global food security and sustainable development. J. Food Composit. Anal., 19: 477-483.

DOI: 10.1016/j.jfca.2006.05.001

De Caluwé, E., K. Halamová and P. Van Damme, 2010. Tamarindus indica L. - A review of traditional uses, phytochemistry and pharmacology. Afrika Focus, 23: 53-83. DOI: 10.21825/af.v23i1.5039

Diehl, M.S., K.K. Atindehou, H. Téré and B. Betschart, 2004. Prospect for anthelminthic plants in the Ivory Coast using ethnobotanical criteria. J. Ethnopharmacology, 95: 277-284. DOI: $10.1016 /$ j.jep.2004.07.012

Elumalai, A., N. Mathangi, A. Didala, R. Kasarla and Y. Venkatesh, 2012. A review on Ceiba pentandra and its medicinal features. Asian J. Pharmacy Technology, 2: 83-86.

Ermias, L.M., A. Zemede, K. Ensermu and V.D. Patrick, 2011. Wild edible plants in Ethiopia: A review on their potential to combat food insecurity. Afrika Focus, 24: 71-121.

Esmaeili, A., L. Moaf, S. Rezazadeh and M. Ayyari, 2014. antioxidant and antibacterial activity of various extracts of Malcolmia Africana (L.). Zahedan J. Res. Medical Sci., 16: 6-11. http://zjrms.ir/article-1-2694-en.html

Freedman, R.L., 2015. Indigenous wild food plants in home gardens: improving health and income with the assistance of agricultural extension. Int. J. Agric. Extension, 3: 63-71.

Friday, E.T., O. James, O. Olusegun and A. Gabriel, 2011. Investigations on the nutritional and medicinal potentials of Ceiba pentandra leaf: A common vegetable in Nigeria. Int. J. Plant Physiol. Biochem., 3: 95-101. DOI: 0.5897/IJPPB

Hellmuth, N.M, 2011. Ceiba pentandra: A sacred tree for classic Maya, national tree for Guatemala today. Revue Magazine, pp: 1-3.

Heywood, V.H., 2011. Ethnopharmacology, food production, nutrition and biodiversity conservation: Towards a sustainable future for indigenous peoples. J. Ethnopharmacology, 137: 1-15. DOI: $10.1016 /$ j.jep.2011.05.027

Hussain, I. and I. Khan, 2010. Investigation of heavy metals content in medicinal plant, Eclipta alba L. J. Chemical Society Pakistan, 32: 28-33. 
Imran, M., F. Talpur, M.I. Jan, A. Khan and I. Khan, 2007. Analysis of nutritional components of some wild edible plants. J. Chemical Society Pakistan, 29: 500-508.

Janu, C., D.R. Sobankumar, M.V. Reshma, P. Jayamurthy and A. Sundaresan et al., 2014. Comparative study on the total phenolic content and radical scavenging activity of common edible vegetable oils. J. Food Biochemistry, 38: 38-49. DOI: 10.1111/jfbc. 12023

Khan, H., S.A. Jan, M. Javed, R. Shaheen and Z. Khan, et al., 2016. Nutritional composition, antioxidant and antimicrobial activities of selected wild edible plants. J. Food Biochemistry, 40: 61-70. DOI: $10.1111 /$ jfbc. 12189

Kwazo, H.A., U.Z. Faruq, S.M Dangoggo, B.S. Malami and D.O. Moronkola, 2015. Antimicrobial activity and phytochemical screening of crude water extract of the stem bark of Ficus glumosa. Scientific Res. Essays, 10: 177-183. DOI: 10.5897/SRE

Munro, A. and O. Bassir, 1969. Oxalate in Nigerian vegetables. West African J. Applied Chemistry, 12: 14-18.

Mutiara, T.K., H. Harijono, T. Estiasih and E. Sriwahyuni, 2013. Effect of blanching treatments against protein content and amino acid drumstick leaves (Moringa oleifera). J. Food Res., 2: 100-108.

DOI: $10.5539 /$ jfr.v2n1p101

Nelson, D.L. and M.M. Cox, 2012. Lehninger Principles of Biochemistry. 6th Edn., Macmillan Learning, New York: W.H. Freeman Company, ISBN-10: 1464109621, pp: 1198.

Ntchapda, F., A. Djedouboum, E. Talla, D. Sokeng and P. Nana et al., 2015. Hypolipidemic and antiatherogenic effect of aqueous extract leaves of Ficus glumosa (Moraceae) in rats. Experimental Gerontology, 62: 53-62.

DOI: 0.1016/j.exger.2014.12.015

Onwuka, G., 2005. Food Analysis and Instrumentation, Theory and Practice. 1st Edn., Lagos: Naphtali Prints, pp: 219.
Onyeike, E.N., E.O. Ayalogu and C.O. Ibegbulem, 2000. Evaluation of the nutritional value of some crude oil polluted freshwater fishes. Global J. Pure Applied Sci., 6: 227-233.

Pollard, E., C. Rosenberg and R. Tignor, 2015. Worlds Together, Worlds Apart: A History of the World: from the Beginnings of Humankind to the Present. 1st Edn., New York: Norton and Company, ISBN-10: 0393250946, pp: 624.

Sandi, S., F. Yosi and Miksusanti, 2016. Performance and protein efficiency ratio of starter phase pegagan ducks fed fermented rations made from locally sourced materials. Pak. J. Nutrition, 15: 268-273. DOI: $10.3923 /$ pjn.2016.268.273

Shermer, M., 2002. The Borderlands of Science. 1st Edn., Oxford University Press, Oxford, ISBN-10: 0195157982, pp: 360.

Siddique, A. and J. Prakash, 2014. Dietary fibre and related antioxidant components from cereal sources and their role in health: A review. Trends Carbohydrate Res., 6: 1-19.

Singhal, P., S.K. Jha, V.K. Thakur, P.M. Ravi and A.C. Patra et al., 2016. Assessment of Trace Element Intake through Some Vegetables to the Population of Mumbai. Vitam Miner, 5: 135. DOI: $10.4172 / 2376-1318.1000135$

Udo, S., Obi-Abang, M, Okoi A. and P. Akwaji, 2013. Nutrition and antinutritional components of two popular lesser known vegetables in farming communities of Cross River State, Nigeria. Int. J. Applied Natural Sci., 2: 85-90.

Vaskonen, T., 2003. Dietary minerals and modification of cardiovascular risk factors. J. Nutritional Biochem., 14: 492-506. DOI: $10.1016 / \mathrm{S} 0955-2863(03) 00074-3$

Weidmann, J. and D.J. Craik, 2016. Discovery, structure, function and applications of cyclotides: Circular proteins from plants. J. Experimental Biology, 67: 4801-4812. DOI: $10.1093 / \mathrm{jxb} / \mathrm{erw} 210$

WHO, 1979. Sodium, chlorides and conductivity in drinking-water. Report on a Working Group, May 1-5, Regional Office for Europe, World Health Organization, Hague. 